\title{
Quantitative analysis of RNA abondance for CTCF during reprogramming of bovine embryo from oocyte to blastocyst
}

\author{
M. Amiri Roudbar ${ }^{1}$, H. Dehghani ${ }^{2}$, M. Tahmoorespur ${ }^{1}$, A. Zahmatkesh ${ }^{3}$, H. Adeldust ${ }^{4}$, S. Ansari Majd , $^{5}$ \\ and M. Daliri Joupari ${ }^{5}$ \\ ${ }^{1}$ Department of Animal Sciences, College of Agriculture, Ferdowsi University of Mashhad, Mashhad, Iran \\ ${ }^{2}$ Department of Basic Science, Faculty of Veterinary Medicine, Ferdowsi University of Mashhad, \\ Mashhad, Iran \\ ${ }^{3}$ Department of Animal Sciences, College of Agriculture, Isfahan University of Technology, Isfahan, Iran \\ ${ }^{4}$ Department of Animal Science, College of Agriculture, University of Tehran, Tehran, Iran \\ ${ }^{5}$ Department of Animal and Marine Biotechnology, National Institute of Genetic Engineering and \\ Biotechnology, Tehran, Iran
}

Correspondence to: M. Daliri Joupari (daliri@nigeb.ac.ir)

Received: 29 January 2014 - Accepted: 26 March 2015 - Published: 28 April 2015

\begin{abstract}
CTCF is a highly conserved protein among eukaryotes and it is involved in many of regulatory functions including, transcriptional repression and activation, chromatin insulation, imprinting, $\mathrm{X}$ chromosome inactivation, higher-order chromatin organization, and alternative splicing. Studies performed on mouse embryos indicate that CTCF can be a maternal-effect gene, and is essential for normal development of embryos. CTCF can be used as a molecular effector for the proper epigenetic establishment of embryonic development. The aim of this study was to determine changes in transcript levels of the CTCF gene in bovine preimplantation embryos. RNA was extracted from immature and mature oocytes and embryos at various developmental stages (two-cell, four-cell, eight-cell, and blastocysts). Results showed that the amounts of CTCF transcripts decreased in mature oocyte in comparison with immature oocytes, but this change was not significant. In addition, the amount of CTCF transcript in embryos at two-cell, four-cell, eight-cell, and blastocyst stages significantly increased in comparison with immature oocytes. These data show that CTCF expression in bovine embryo begins at minor embryonic genome activation.
\end{abstract}

\section{Introduction}

Linear models of studies on gene expression has developed and changed into three-dimensional models of gene expression profiling. These studies suggest the existence of factors that have roles in higher-order chromatin organization. CTCF is a good candidate to play this important role. These findings have led to recognizing this protein as a master weaver of the genome (Phillips and Corces, 2009). CCCTC binding factor (CTCF) is a highly conserved protein among eukaryotes, which is expressed in almost all somatic cells similar to housekeeping genes. CTCF is able to bind to a wide range of various sequences, and this ability is based on combinato- rial use of its different zinc finger domains (Filippova et al., 1996). Existence of 39609 binding sites in the genome of mouse embryonic stem cells and 28 661, 19308, and 19572 binding sites in the genome of human $\mathrm{CD} 4+\mathrm{T}$ cells, HeLa cells, and Jurkat cells, respectively, for CTCF illustrates a very important role for this binding protein (Cuddapah et al., 2009; Chen et al., 2008).

CTCF was discovered for the first time as a transcriptional repressor (Klenova et al., 1993), and subsequent investigations revealed that $\mathrm{CTCF}$ is able to act as a transcriptional activator factor (Vostrov and Quitschke, 1997). Investigations of insulators, which are important epigenetic regulators, showed that CTCF is necessary for the perfor- 
mance of enhancer blocker (EB) insulators (Bell et al., 1999). Methylation-sensitive CTCF binding sites are important segments for the regulation of methylation at imprinted regions (Hark et al., 2000). Interestingly, CTCF as a multifunctional factor regulates both active and inactive $\mathrm{X}$ chromosomes (Chao et al., 2002; Pugacheva et al., 2005).

Alternative splicing plays a very important role during development and differentiation. It has recently has been determined that there is a close relationship between alternative splicing and epigenetic mechanisms (Luco et al., 2011). Studies have shown that CTCF binds to the unmethylated region of exon 5 of CD45 gene, and regulates alternative splicing (Shukla et al., 2011). This very important finding provides a new perspective of studies on this gene.

Despite the increase in our understandings of CTCF function in recent years and the crucial role of this gene in epigenetic regulation, there is no research describing CTCF expression pattern during the preimplantation period of bovine embryos. Understanding CTCF expression patterns during reprogramming, therefore, can help us improve our knowledge about gene expression patterns during the preimplantation period of bovine embryos. Accordingly, the aim of this study was to determine the amounts of CTCF transcripts at various stages of embryo development using realtime PCR.

\section{Material and methods}

All reagents were purchased from Sigma Aldrich Company (Seelze, Germany) unless otherwise specified.

\subsection{Oocyte collection}

Bovine ovaries and testes were collected from a commercial slaughterhouse. These samples were transported to the laboratory in a standard saline solution at 30 to $35^{\circ} \mathrm{C}$ within $2 \mathrm{~h}$. Cumulus-oocyte complexes (COCs) were collected from 2 to $8 \mathrm{~mm}$ follicles by aspiration using an 18 gauge needle and a $20 \mathrm{~mL}$ syringe. The COCs were selected according to morphological characteristic (Wei et al., 2001) and washed three times in the aspiration medium (TCM-199 supplemented with $3 \mathrm{mg} \mathrm{mL}^{-1} \mathrm{BSA}, 20 \mathrm{mM}$ sodium pyruvate and $50 \mathrm{~g} \mathrm{~mL}^{-1}$ gentamicin sulfate). Some of the COCs were vortexed to separate the cumulus cells from the oocytes. These immature oocytes were washed three times with phosphate buffer saline (PBS) and were immediately stored at $-70^{\circ} \mathrm{C}$ until the time of RNA extraction.

\subsection{In vitro maturation (IVM)}

Aspirated COCs were washed three times in the maturation medium (TCM-199 supplemented with $10 \%$ fetal bovine serum (FBS), $20 \mathrm{mM}$ sodium pyruvate, $50 \mathrm{ng} \mathrm{mL}^{-1}$ epidermal growth factor (EGF), $0.5 \mathrm{mg} \mathrm{mL}^{-1}$ follicle stimulating hormone (FSH), $5 \mathrm{mg} \mathrm{mL}^{-1}$ luteinizing hormone (LH), and $50 \mathrm{~g} \mathrm{~mL}^{-1}$ gentamicin sulfate). Groups of 10 oocytes were incubated in droplets of $50 \mu \mathrm{L}$ maturation medium under mineral oil for $23-24 \mathrm{~h}$ at $38.5^{\circ} \mathrm{C}$ with $5 \% \mathrm{CO}_{2}$. After incubation, some of the mature oocytes were vortexed to separate the cumulus cells. Oocytes were washed three times with PBS and were immediately stored at $-70^{\circ} \mathrm{C}$ until the time of RNA extraction.

\subsection{In vitro fertilization (IVF)}

Motile sperm cells were obtained from fresh epididymis of collected testes. Sperm cells were washed two times in HEPES TALP medium and were separated by the swimup method. Some matured oocytes with expanded cumulus cells were washed three times in TCM199 supplemented with $3 \mathrm{mg} \mathrm{mL}^{-1}$ BSA. Groups of 10 matured oocytes were transferred into $50 \mu \mathrm{L}$ droplets of fertilization medium (IVF-TALP supplemented with $25 \mu \mathrm{gL}^{-1}$ heparin and $6 \mathrm{mg} \mathrm{mL}^{-1}$ fatty acid free BSA). To each droplet, $10 \mu \mathrm{L}$ of $2 \times 10^{6}$ sperm concentration was added and plates were incubated for $22 \mathrm{~h}$ at $38.5^{\circ} \mathrm{C}$ and $5 \% \mathrm{CO}_{2}$.

\subsection{In vitro culture (IVC)}

After fertilization, presumptive zygotes were denuded from cumulus cells by slow pipetting. Zygotes were washed two times in the culture medium (human embryo sequential media G1/G2 containing $10 \mathrm{ng} \mathrm{mL}^{-1}$ EGF and $5 \%$ FBS). The first group of 50 zygotes were cultured in four-well petri plates containing $250 \mu \mathrm{L}$ of G1 medium and incubated for $72 \mathrm{~h}$ at $38.5^{\circ} \mathrm{C}$ and $5 \% \mathrm{CO}_{2}$. After $72 \mathrm{~h}$, embryos were transferred to another four-well petri plate containing $250 \mu \mathrm{L}$ of G2 medium and cultured for 4 to 6 days until the blastocyst stage. Samples of different embryonic stages including twocell, four-cell, eight-cell, and blastocysts were collected at various time intervals (30-36, 36-72, 72-96 h, and 7-9 days respectively). Embryos were isolated and washed three times with PBS and immediately stored at $-70^{\circ} \mathrm{C}$ until the time of RNA extraction.

\subsection{RNA extraction and RT reaction}

Polled samples of 50 immature, 50 mature oocytes, $40 \mathrm{em}$ bryos at two-cell stage, 30 embryos at four-cell stage, $20 \mathrm{em}-$ bryos at eight-cell stage, and 10 embryos at blastocyst stage were used. All extractions of collected samples (immature and mature oocytes, embryos at two-cell, four-cell, eightcell, and blastocyst stage) were done by Qiagen RNeasy ${ }^{\circledR}$ Plus Micro Kit according to the manufacturer's procedure. DNase I treatment was performed to remove genomic DNA from the samples according to the manufacturer's procedure (Roche Applied Science). RNA was reverse transcribed to cDNA with random primers and reverse transcriptase (Fermentas). 
Table 1. Primers used for realtime PCR.

\begin{tabular}{llllc}
\hline Gene & GenBank accession number & Animal & Sequence & Product size (bp) \\
\hline H2A & U62674 & Mouse & 5'-GTCGTGGCAAGCAAGGAG-3' $^{\prime}$ & 182 \\
& & & 5'-GATCTCGGCCGTTAGGTACTC-3' $^{\prime}$ & \\
\hline CTCF & NM_001075748.1 & Cow & 5'-AGCCACTGCGACAAGACCTTC-3' $^{\prime}$ & 171 \\
& & & 5'ACCATCTGGACCAGCACAATT-3' $^{\prime}$ & \\
\hline
\end{tabular}

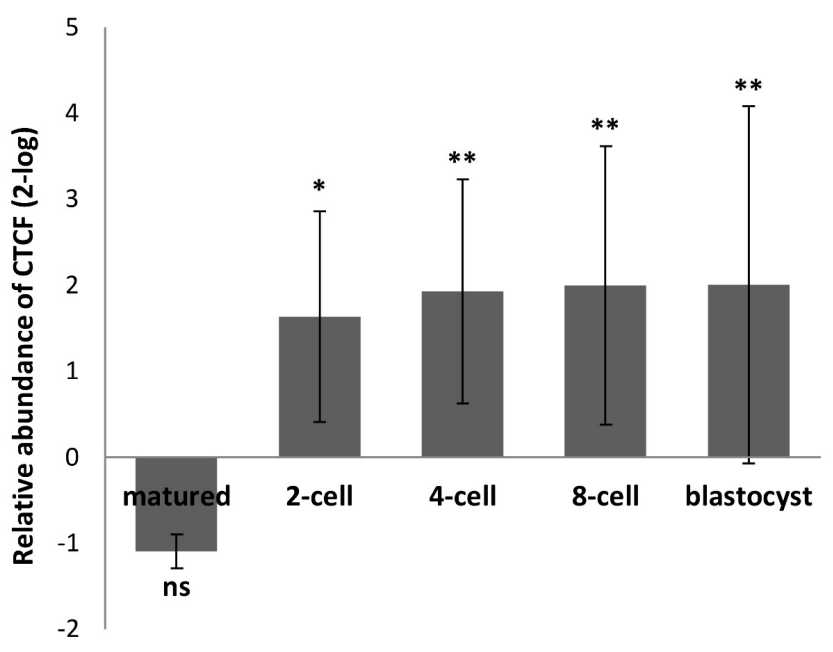

Figure 1. Relative abundance of CTCF in various stages of bovine embryonic development. Data are shown as folds of transcript levels (2-log) \pm SE. ns: not significantly different from immature oocyte $(P>0.05), *$ and $* *$ : significantly different from immature oocyte $(P<0.05$ and $P<0.01$, respectively).

\subsection{Realtime PCR and analysis of data}

Realtime PCR was performed for CTCT as the target gene and $\mathrm{H} 2 \mathrm{~A}$ as an internal control (all tests had three biological and technical replicates). H2A was selected based on previous reports (Lonergan et al., 2003; Robert et al., 2002). In this study two pairs of primers were used (Table 1).

Realtime PCR reaction was performed by Rotor-Gene 6000 (Corbett Research, Australia), using Light Cycler ${ }^{\circledR} 480$ SYBER Green I Master mix kit (Roche Applied Science) according to the manufacturer's procedure. The PCR procedure was performed by an initial denaturation at $95^{\circ} \mathrm{C}$ for $10 \mathrm{~min}$ followed by 40 cycles of denaturation for $5 \mathrm{~s}$ at $95^{\circ} \mathrm{C}$, annealing for $10 \mathrm{~s}$ at $60^{\circ} \mathrm{C}$, and extension for $20 \mathrm{~s}$ at $72^{\circ} \mathrm{C}$ for both genes.

In order to determine the amount of transcripts of the CTCF gene, raw data were obtained from the system and CT information and amplification efficiencies were determined using Linreg software (http://LinRegPCR.HFRC.nl) based on baseline fluorescence collected during PCR (Ramakers et al., 2003). Then these data were analyzed using REST software based on the Pfaffl method (Pfaffl, 2001; Pfaffl et al., 2002).

\section{Results}

The amounts of CTCF transcripts at various stages of preimplantation embryos were compared with immature oocyte (germinal vesicle GV) as control. Comparisons are presented as expression ratio (2-log scale) \pm SE (based on biological replicates). In this study, the amounts of CTCF transcripts in matured oocytes declined (not significantly) whereas embryos at two-cell, four-cell, eight-cell, and blastocyst stage showed significant increases of CTCF transcript levels (Fig. 1).

\section{Discussion}

Maternal-effect genes are necessary for normal embryonic development (Wan et al., 2008). Depletion of CTCF by using transgenic RNAi mouse, indicated that CTCF can be a maternal-effect gene. In mice, depletion of the CTCF caused many of genes to become misregulated at early stages of embryogenesis. These results indicated that CTCF has global and essential roles in oogenesis and embryogenesis in mice (Wan et al., 2008; Moore et al., 2012).

Preimplantation development can be classified in different steps, including first cleavage division, activation of the embryonic genome, compaction and blastocyst formation. For the proper execution of these steps, the genes should be expressed in a coordinated manner. Transcripts in oocytes or embryos can be from the source of maternal or embryonic genome (Memili and First, 2000). In mice, about 15700 genes are expressed during preimplantation development (Stanton et al., 2003), and the same number of genes are expected to be expressed in cattle at this period. Precise regulation of the expression patterns of these genes at the preimplantation period requires correct reprogramming of the genome (Gondor and Ohlsson, 2009). Our knowledge is quickly increasing about the expression pattern of genes during preimplantation period. The proper expression pattern is very important for the normality and quality of embryos (Wrenzycki et al., 2005). Using a gene expression pattern is a powerful tool to estimate embryo quality and viability at this sensitive stage (Wrenzycki et al., 2007). According to recent studies, CTCF was considered as a very important factor involved in many parts of epigenetic regulation (Filippova, 2007) and, moreover, it may act as a heritable factor for epigenetic regulation (Phillips and Corces, 2009). Thus, 
CTCF can be used as a molecular marker for the proper establishment of epigenetic mechanisms during preimplantation development.

A very important event that occurs during mammalian embryonic development is the replacement of maternal transcripts with embryonic transcripts. This is performed in two phases of minor (after fertilization) and major (8- to 16cell) embryonic genome activation (Badr et al., 2007). Data in this study reveal that CTCF expression of the embryonic genome began at minor embryonic genome activation, similar to mice at the two-cell embryo stage (Wan et al., 2008). At major activation, the amount of the CTCF transcripts were increased slightly. CTCF transcripts declined at maturation period, probably due to the degradation of the maternal CTCF transcripts and inactive embryonic genome.

CTCF has more than tens of thousands the binding sites throughout the mammalian genome (Kim et al., 2007). The DNA-binding property of CTCF is sensitive to methylation (Hark et al., 2000). In the reprogramming process, the whole bovine genome undergoes gradual demethylation during the preimplantation period until the 8- to 16-cell stages. After this stage, the genome undergoes de novo methylation (Mann and Bartolomei, 2002). From fertilization to 8- to 16-cell stages, we expect to witness that the binding sites for CTCF to increase with demethylation. In our study, the amount of CTCF transcripts increased after fertilization, which is probably coordinate with the increase in binding sites for CTCF.

In this study, the amount of CTCF transcripts were obtained at in vitro conditions. These changes may be the observed changes related to environmental effects. The amount of transcripts in the early preimplantation period can vary in different conditions, such as in vivo versus in vitro (Lonergan et al., 2003). The quantitation of transcripts at in vivo conditions may be a useful marker for showing expression differences in the two cases.

Acknowledgements. The authors would like to acknowledge the National Institute of Genetic Engineering and Biotechnology (NIGEB, Tehran, Iran) for their financial support.

Edited by: K. Wimmers

Reviewed by: two anonymous referees

\section{References}

Badr, H., Bongioni, G., Abdoon, A. S., Kandil, O., and Puglisi, R.: Gene expression in the in vitro-produced preimplantation bovine embryos, Zygote, 15, 355-367, 2007.

Bell, A. C., West, A. G., and Felsenfeld, G.: The Protein CTCF Is Required for the Enhancer Blocking Activity of Vertebrate Insulators, Cell, 98, 387-396, 1999.

Chao, W., Huynh, K. D., Spencer, R. J., Davidow, L. S., and Lee, J. T.: CTCF, a candidate trans-acting factor for X-inactivation choice, Science, 295, 345-347, 2002.
Chen, X., Xu, H., Yuan, P., Fang, F., Huss, M., Vega, V. B., Wong, E., Orlov, Y. L., Zhang, W., Jiang, J., Loh, Y.-H., Yeo, H. C., Yeo, Z. X., Narang, V., Govindarajan, K. R., Leong, B., Shahab, A., Ruan, Y., Bourque, G., Sung, W.-K., Clarke, N. D., Wei, C.-L., and $\mathrm{Ng}, \mathrm{H} .-\mathrm{H}$.: Integration of External Signaling Pathways with the Core Transcriptional Network in Embryonic Stem Cells, Cell, 133, 1106-1117, 2008.

Cuddapah, S., Jothi, R., Schones, D. E., Roh, T.-Y., Cui, K., and Zhao, K.: Global analysis of the insulator binding protein CTCF in chromatin barrier regions reveals demarcation of active and repressive domains, Genome Res., 19, 24-32, 2009.

Filippova, G. N.: Genetics and Epigenetics of the Multifunctional Protein CTCF, in: Current Topics in Developmental Biology, edited by: Gerald, P. S., Academic Press, 80, 337-360, 2007.

Filippova, G. N., Fagerlie, S., Klenova, E. M., Myers, C., Dehner, Y., Goodwin, G., Neiman, P. E., Collins, S. J., and Lobanenkov, V. V.: An exceptionally conserved transcriptional repressor, CTCF, employs different combinations of zinc fingers to bind diverged promoter sequences of avian and mammalian cmyc oncogenes, Mol. Cell. Biol., 16, 2802-2813, 1996.

Gondor, A. and Ohlsson, R.: OPINION Replication timing and epigenetic reprogramming of gene expression: a two-way relationship?, Nat. Rev. Genet., 10, 269-276, 2009.

Hark, A. T., Schoenherr, C. J., Katz, D. J., Ingram, R. S., Levorse, J. M., and Tilghman, S. M.: CTCF mediates methylation-sensitive enhancer-blocking activity at the H19/Igf2 locus, Nature, 405, 486-489, 2000.

Kim, T. H., Abdullaev, Z. K., Smith, A. D., Ching, K. A., Loukinov, D. I., Green, R. D., Zhang, M. Q., Lobanenkov, V. V., and Ren, B.: Analysis of the Vertebrate Insulator Protein CTCF-Binding Sites in the Human Genome, Cell, 128, 1231-1245, 2007.

Klenova, E. M., Nicolas, R. H., Paterson, H. F., Carne, A. F., Heath, C. M., Goodwin, G. H., Neiman, P. E., and Lobanenkov, V. V.: $\mathrm{CTCF}$, a conserved nuclear factor required for optimal transcriptional activity of the chicken c-myc gene, is an 11-Zn-finger protein differentially expressed in multiple forms, Mol. Cell. Biol., 13, 7612-7624, 1993.

Lonergan, P., Rizos, D., Gutierrez-Adan, A., Moreira, P. M., Pintado, B., de la Fuente, J., and Boland, M. P.: Temporal divergence in the pattern of messenger RNA expression in bovine embryos cultured from the zygote to blastocyst stage in vitro or in vivo, Biol. Reprod., 69, 1424-1431, 2003.

Luco, R. F., Allo, M., Schor, I. E., Kornblihtt, A. R., and Misteli, T.: Epigenetics in alternative pre-mRNA splicing, Cell, 144, 16-26, 2011.

Mann, M. R. and Bartolomei, M. S.: Epigenetic reprogramming in the mammalian embryo: struggle of the clones, Genome Biol., 3, reviews1003.1-reviews1003.4, 2002.

Memili, E. and First, N. L.: Zygotic and embryonic gene expression in cow: a review of timing and mechanisms of early gene expression as compared with other species, Zygote, 8, 87-96, 2000.

Moore, J. M., Rabaia, N. A., Smith, L. E., Fagerlie, S., Gurley, K., Loukinov, D., Disteche, C. M., Collins, S. J., Kemp, C. J., Lobanenkov, V. V., and Filippova, G. N.: Loss of Maternal CTCF Is Associated with Peri-Implantation Lethality of Ctcf Null Embryos, PLoS ONE, 7, e34915, doi:10.1371/journal.pone.0034915, 2012. 
Pfaffl, M. W.: A new mathematical model for relative quantification in real-time RT-PCR, Nucleic Acids Res., 29, e45, doi:10.1093/nar/29.9.e45, 2001.

Pfaffl, M. W., Horgan, G. W., and Dempfle, L.: Relative expression software tool $\left(\right.$ REST $^{\circledR}$ ) for group-wise comparison and statistical analysis of relative expression results in real-time PCR, Nucleic Acids Res., 30, e36, doi:10.1093/nar/30.9.e36, 2002.

Phillips, J. E. and Corces, V. G.: CTCF: master weaver of the genome, Cell, 137, 1194-1211, 2009.

Pugacheva, E. M., Tiwari, V. K., Abdullaev, Z., Vostrov, A. A., Flanagan, P. T., Quitschke, W. W., Loukinov, D. I., Ohlsson, R., and Lobanenkov, V. V.: Familial cases of point mutations in the XIST promoter reveal a correlation between CTCF binding and pre-emptive choices of $\mathrm{X}$ chromosome inactivation, Hum. Mol. Genet., 14, 953-965, 2005.

Ramakers, C., Ruijter, J. M., Deprez, R. H., and Moorman, A. F.: Assumption-free analysis of quantitative real-time polymerase chain reaction (PCR) data, Neurosci. Lett., 339, 62-66, 2003.

Robert, C., McGraw, S., Massicotte, L., Pravetoni, M., Gandolfi, F., and Sirard, M.-A.: Quantification of Housekeeping Transcript Levels During the Development of Bovine Preimplantation Embryos, Biol. Reprod., 67, 1465-1472, 2002.

Shukla, S., Kavak, E., Gregory, M., Imashimizu, M., Shutinoski, B., Kashlev, M., Oberdoerffer, P., Sandberg, R., and Oberdoerffer, S.: CTCF-promoted RNA polymerase II pausing links DNA methylation to splicing, Nature, 479, 74-79, 2011.
Stanton, J., Macgregor, A., and Green, D.: Gene expression in the mouse preimplantation embryo, Reproduction, 125, 457-468, 2003.

Vostrov, A. A. and Quitschke, W. W.: The Zinc Finger Protein CTCF Binds to the APB $\beta$ Domain of the Amyloid $\beta$-Protein Precursor Promoter, J. Biol. Chem., 272, 33353-33359, 1997.

Wan, L.-B., Pan, H., Hannenhalli, S., Cheng, Y., Ma, J., Fedoriw, A., Lobanenkov, V., Latham, K. E., Schultz, R. M., and Bartolomei, M. S.: Maternal depletion of CTCF reveals multiple functions during oocyte and preimplantation embryo development, Development, 135, 2729-2738, 2008.

Wei, Z., Park, K.-W., Day, B. N., and Prather, R. S.: Effect of epidermal growth factor on preimplantation development and its receptor expression in porcine embryos*, Mol. Reprod. Dev., 60, 457-462, 2001.

Wrenzycki, C., Herrmann, D., Lucas-Hahn, A., Korsawe, K., Lemme, E., and Niemann, H.: Messenger RNA expression patterns in bovine embryos derived from in vitro procedures and their implications for development, Reprod. Fert. Develop., 17, 23-35, 2005.

Wrenzycki, C., Herrmann, D., and Niemann, H.: Messenger RNA in oocytes and embryos in relation to embryo viability, Theriogenology, 68, Suppl. 1, S77-83, 2007. 